\title{
Determination of tocopherols and physicochemical properties of faveleira (Cnidoscolus quercifolius) seed oil extracted using different methods
}

\author{
Penha Patrícia Cabral RIBEIRO로 , Denise Maria de Lima e SILVA ${ }^{1}$, Mariana Mesquita DANTAS², \\ Karla Danielly da Silva RIBEIRO ${ }^{1}$, Roberto DIMENSTEIN ${ }^{3}$, \\ Karla Suzanne Florentino da Silva Chaves DAMASCENO ${ }^{1 *}$
}

\begin{abstract}
This study aims to evaluate the physicochemical properties and tocopherol content in faveleira seed oil extracted using three methods (Bligh-Dyer, Soxhlet extractor, and cold-pressing). Each of the methods generated different yield percentages, with cold-pressing producing the least amount of oil. However, the cold-pressing method produced better quality oil with more desirable properties, including low acidity ( $1.56 \pm 0.01 \%$ oleic acid $)$ and low peroxide value $(0.45 \pm 0.09 \mathrm{mEq} / 1000 \mathrm{~g})$. Cold-pressing resulted in higher quantities of tocopherols: $0.59 \pm 0.12 \mathrm{mg} / 100 \mathrm{~g}$ of alpha-tocopherol and $20.97 \pm 1.15 \mathrm{mg} / 100 \mathrm{~g}$ of beta + gamma-tocopherol. Faveleira seed oil, when extracted by cold-pressing, maintains better physicochemical quality, with the highest beta + gamma-tocopherol content.
\end{abstract}

Keywords: oilseed; vegetable oil; physicochemical characteristics; vitamin E.

Practical Application: The oil from the faveleira obtained by cold-pressing can be consumed and has higher tocopherols.

\section{Introduction}

Faveleira (Cnidoscolus quercifolius) is a species found in the Caatinga in Brazil (Silva et al., 2014). It stands out among other species for its high resistance to drought (Santos et al., 2017). The faveleira seed has high nutritional and industrial value (Medeiros et al., 2018) and is an oilseed with lipid levels (Ribeiro et al., 2017) higher than those in soybean, an oilseed of global importance (Anwar et al., 2016).The faveleira oil has potential for use as edible oil, high antioxidant activity and good thermal and oxidative stability (Santos et al., 2017), and predominance of unsaturated fatty acids (Ribeiro et al., 2017).

There is currently a large commercial demand for vegetable oils rich in compounds beneficial to health because of consumer interest in reducing disease risk and promoting health through improved nutrition (Jing et al., 2016). In addition, compounds that can protect foods against deterioration by extending their shelf life are also of interest in the food industry (Xu et al., 2015). Among these compounds, vitamin $\mathrm{E}$ is a major lipid-soluble antioxidant (Gharby et al., 2017).

The term "Vitamin E" encompasses, among other compounds, tocopherols and tocotrienols (Traber, 2012). Tocopherols are the main lipophilic antioxidants found in oilseeds and are extracted during the processing of these seeds. This makes tocopherols a naturally occurring antioxidant in most vegetable oils (Gharby et al., 2017). There are four homologs within the tocopherol group: alpha $(\alpha)$, beta $(\beta)$, gamma $(\gamma)$, and delta
( $\delta)$ (Traber, 2012), which differ in their antioxidant activities (Gharby et al., 2017). Alpha-tocopherol has the highest in vivo biological activity and the gamma-tocopherol has the most activity in food lipids (Tuberoso et al., 2007). Consequently, foods with tocopherols may be beneficial to human health and promote the stability of foods (Flakelar et al., 2015).

Santos et al. (2017) identified and quantified the levels of alpha-, gamma- and delta-tocopherols in the extracted faveleira oil using a Soxhlet extractor $(0.87,15.09$ and $3.15 \mathrm{mg} / 100 \mathrm{~g}$ oil, respectively). Vegetable oil can be obtained by various methods, which may influence some of its properties such as quality, oxidative stability, and other physicochemical properties (Gharby et al., 2017). The Soxhlet method has high efficacy and is widely used. However, heating, exposure to oxygen for a long time, and use of toxic solvents during this method alter the composition of the oil and also degrades the quality (Brum et al., 2009).

An alternative to the Soxhlet method is the methodology described by Bligh \& Dyer (1959). Authors claim that the latter is not harmful to the quality of the oil. This method can be very efficient, since the solvent mixture used (methanol, chloroform, and water) and the vigorous homogenization process allow an efficient extraction of polar and apolar lipids (Brum et al., 2009). However, it is a method that also uses toxic solvents.

Cold-pressing stands out in the extraction of oils from plant seeds. Cold-pressing neither involves the use of toxic 
solvents nor does it employ high temperatures. Consequently, the physicochemical characteristics of the oil and the bioactive compounds, such as tocopherols, are not significantly affected by the processing condition. This ensures high quality cold-pressed oils, which do not have to go through refinement to be consumed (Teh \& Morlock, 2015). The amount of oil extracted, however, is lower than the amount obtained by solvent extraction.

No study compared the resultant characteristics of faveleira seed oils extracted by these different methods. This study is relevant because faveleira oil has great potential for use in human consumption and is obtained from an oilseed that, although underexplored, is already used by the population. This study evaluated the physicochemical properties and tocopherol content in faveleira seed oil extracted using three different methods.

\section{Materials and methods}

\subsection{Samples}

Fruits of Cnidoscolus quercifolius were collected from São José do Seridó, a municipality in the State of Rio Grande do Norte, Brazil. A specimen of faveleira (no. 20064) was deposited in the Herbarium of the Federal University of Rio Grande do Norte. Several fruits were harvested and pooled to form a single sample. Seeds were removed manually from the fruits, and $2.4 \mathrm{~kg}$ of seeds was obtained. These seeds were equally divided into three groups ( $800 \mathrm{~g}$ of seeds to be subjected to each extraction method) and stored at $-20^{\circ} \mathrm{C}$ until oil extraction. The percent yield of each extraction method was calculated by dividing the weight of the oil extracted by the weight of the seeds used and multiplying the result by 100 . All the extractions were performed in triplicate.

\section{Extraction by Soxhlet method}

For extraction according to the Soxhlet method (American Oil Chemists' Society, 1995), the seeds were initially crushed and dried at $105^{\circ} \mathrm{C}$ to a constant weight and transferred to a Soxhlet extractor (Solab, SL 145 V, Piracicaba, Brazil), where they were refluxed for $8 \mathrm{~h}$ with hexane to extract the oil. The extracted faveleira oil using a Soxhlet extractor $\left(\mathrm{FO}_{\text {Sox }}\right)$ was maintained at $-20^{\circ} \mathrm{C}$ until further analysis.

\section{Extraction by Bligh-Dyer method}

The seeds underwent the process of grinding and drying described in section 2.1.1 and were subsequently subjected to extraction by the Bligh-Dyer method (Bligh \& Dyer, 1959), with modifications. To every $50 \mathrm{~g}$ of the sample, $50 \mathrm{~mL}$ of chloroform, $100 \mathrm{~mL}$ of methanol and $50 \mathrm{~mL}$ of distilled water were added. The contents were shaken for 30 min. Fifty milliliters of $1.5 \%$ sodium sulfate was added and stirred for $2 \mathrm{~min}$. The contents were filtered with filter paper and the residue washed with $50 \mathrm{~mL}$ of chloroform. After $30 \mathrm{~min}$ the methanolic layer was discarded. The other layer was filtered with filter paper and $1 \mathrm{~g}$ of sodium sulfate. A speed vacuum (Eppendorf, Concentrator 5301, São Paulo, Brazil) at $60^{\circ} \mathrm{C}$ for $30 \mathrm{~min}$ and an oven with forced air ventilation at $60^{\circ} \mathrm{C}$ for $20 \mathrm{~min}$ were used to evaporate the solvents. The extracted faveleira oil using the Bligh-Dyer method $\left(\mathrm{FO}_{\mathrm{BD}}\right)$ was maintained at $-20^{\circ} \mathrm{C}$ until analysis.

\section{Extraction by cold-pressing}

Cold-pressing was performed by subjecting the seeds in natura to a force of up to $8 \mathrm{t}$ using a hydraulic press (MARCON, MPH-10, Palmital, Brazil) at ambient temperature of $23^{\circ} \mathrm{C}$. The pressing was performed in four batches, with $200 \mathrm{~g}$ of seeds in each batch. The extracted oil was centrifuged (FANEM, Excelsa 4 R 280, São Paulo, Brazil) at $20^{\circ} \mathrm{C}$ for $15 \mathrm{~min}$ at $2500 \times g$, and the supernatant (extracted faveleira oil using cold-pressing, $\mathrm{FO}_{\mathrm{CP}}$ ) was maintained at $-20^{\circ} \mathrm{C}$ until analysis.

\subsection{Physicochemical properties}

The acidity level, peroxide and saponification values, refractive index, moisture content and volatile content (American Oil Chemists' Society, 2009) were measured. The density was analyzed using a densitometer (Anton Paar, DMA 4500 M, São Paulo, Brazil) at $25^{\circ} \mathrm{C}$. The viscosity was measured at $25^{\circ} \mathrm{C}$ using a rheometer (Thermo-Scientific, Haake Mars Rheometer, Massachusetts, USA), and the flow curves were obtained at shear rates varying from 5 to $1010 \mathrm{~s}^{-1}$. All analyses were carried out in triplicate.

\subsection{Sample preparation for high-performance liquid chromatography}

The samples were prepared by adding $160 \mu \mathrm{L}$ of oil sample extracted by each one of the three methods to $840 \mu \mathrm{L}$ of dichloromethane and stirring for $1 \mathrm{~min}$. Dichloromethane was used as the solvent because both oil and methanol (the solvent used in the mobile phase) are highly soluble in dichloromethane (Grilo et al., 2014). This dilution was performed in triplicate for each extraction method.

\subsection{Determination of tocopherols by using high-performance liquid chromatography}

Alpha-, beta-, and gamma-tocopherol levels were determined using high-performance liquid chromatography (HPLC). $20 \mu \mathrm{L}$ of the diluted solution described in section 2.3 was injected directly into a Shimadzu chromatograph consisting of an LC-20 AT pump coupled to an SPD-20A UV-VIS detector, reverse phase column Luna $5 \mu \mathrm{m}$ C18 (2) 100 ÅPhenomenex ${ }^{\circledR}(250 \mathrm{~mm} \times 4.6 \mathrm{~mm})$, and a computer with the LC solution software for data processing (Shimadzu, Quioto, Japan). The mobile phase used was 100\% methanol in an isocratic system at a flow rate of $1 \mathrm{~mL} / \mathrm{min}$ and a wavelength of $292 \mathrm{~nm}$. Ultraviolet detection used in the chromatographic method was standardized in accordance with the IUPAC standards and AOCS (Cert et al., 2000).

Beta-tocopherol could not be separated from gamma-tocopherol by reverse phase-chromatography (Kornsteiner et al., 2006). For that reason, the results were described together (beta + gamma-tocopherol). According to Gliszczynska-Swigło \& Sikorska (2004), vegetable oils either do not contain beta-tocopherol or contain relatively small amounts when compared to the levels of gamma-tocopherol. Thus, to identify the retention time of the beta + gamma-tocopherol, the standards for gamma-tocopherol were used. The retention time and area 
of the alpha- and gamma-tocopherols standards were used for the identification and quantitation of tocopherols.

The concentration of the standards was confirmed using the specific extinction coefficient $(\varepsilon 1 \%, 1 \mathrm{~cm}=75.8$ at $292 \mathrm{~nm}$ for alpha-tocopherol and $\varepsilon 1 \%, 1 \mathrm{~cm}=91.4$ at $298 \mathrm{~nm}$ for gamma-tocopherol) in absolute ethanol (Nierenberg \& Nann, 1992; Podda et al., 1996). The test samples as well as the standards were prepared at approximately $25^{\circ} \mathrm{C}$, protected from light exposure.

Calibration curves for alpha- and gamma-tocopherols were used to assess the linearity of the method: linear regressions were constructed (concentrations of the standards $\times$ standard area) and $R^{2}=0.9993$ and 0.9992 were obtained for alpha- and gamma-tocopherols, respectively. The limits of detection and quantification, based on standard curve linearity, were $2.5 \mathrm{ng} / 20 \mu \mathrm{L}$ and $4.9 \mathrm{ng} / 20 \mu \mathrm{L}$, respectively, for both homologs analyzed.

\subsection{Statistical analysis}

All data were subjected to the Shapiro-Wilk test for normality. The data for yield and physicochemical properties were subjected to analysis of variance (ANOVA), and Tukey's test was used as a post-hoc test. The difference between the homologs for $\mathrm{FO}_{\mathrm{BD}}$ and $\mathrm{FO}_{\mathrm{CP}}$ was calculated using a $t$-test. The significance level for all tests was set at $\mathrm{p}<0.05$, and all statistical analyses were carried out using the Action 2.7 software (Estatcamp, São Carlos, Brazil).

\section{Results and discussion}

\subsection{Yields of the different extraction methods}

The differences in the yields of the different extraction methods were statistically significant $(\mathrm{p}<0.05)$, as shown in Figure 1. The two methods that employed solvents had higher yield percentages, which may be attributed to the increased ability of the organic solvents (when compared to that of cold-pressing) to extract most of the lipid components in the seed

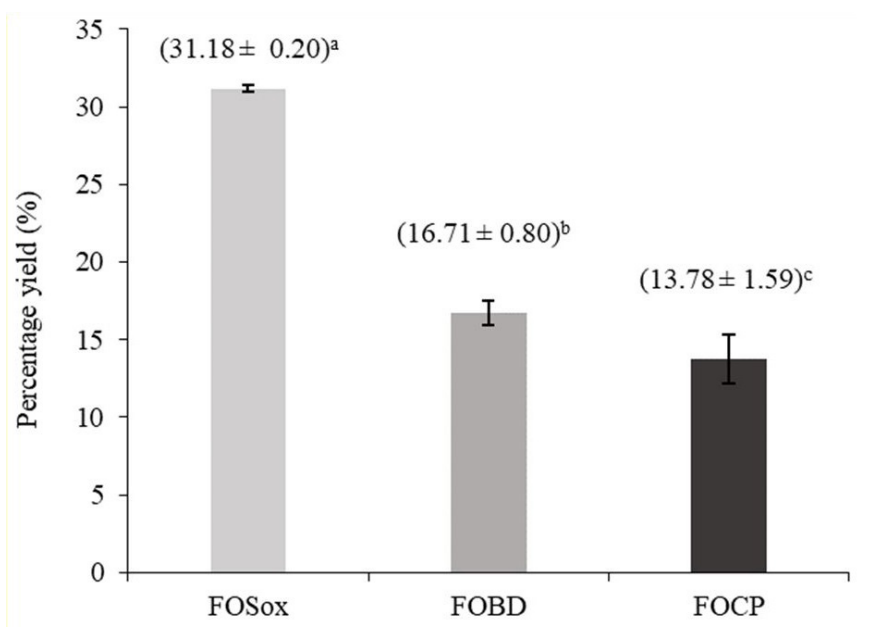

Figure 1. Mean \pm standard error $(n=3)$ of the percentage yield of faveleira seed oil extracted using different methods: Soxhlet (FOSox), Bligh-Dyer (FOBD), and cold-press (FOCP). Different lowercase letters above the columns indicate statistically significant differences $(\mathrm{p}<0.05)$ between the yields according to Tukey's test.
(Perdomo et al., 2013). Chloroform, methanol, and hexane are generally considered the best extraction solvents in a laboratory setting for most oils (Gharibzahedi et al., 2013).

The Soxhlet extraction resulted in a higher yield percentage than Bligh-Dyer extraction $(\mathrm{p}<0.05)$. Several factors may have influenced this result, such as the solvents employed. It is likely that the hexane used in the Soxhlet method can more effectively extract lipid components in seeds than the mixture of chloroform and methanol used in the Bligh-Dyer method. In addition, the high temperatures used and the duration of extraction in the Soxhlet method might have favored higher yield. Teixeira et al. (2018) also observed higher yields from sapucaia nuts when using the Soxhlet extraction method than when using Bligh-Dyer extraction. The cold-pressing of faveleira seeds generated low percent oil yield; this low yield was also reported for the cold-pressing of walnut (Gharibzahedi et al., 2013) and castor seeds (Perdomo et al., 2013).

\subsection{Physicochemical properties}

Table 1 shows physicochemical properties of faveleira seed oil (Cnidoscolus quercifolius). $\mathrm{FO}_{\mathrm{CP}}$ showed better quality since low acidity level and peroxide values indicate better quality of edible oils (Ribeiro et al., 2017). FO ${ }_{C P}$ showed lower acidity $(\mathrm{p}=0.000)$, probably because it was not subjected to high temperatures during the process. Heating promotes the hydrolysis of triglycerides by increasing the amount of free fatty acids (Perdomo et al., 2013). Ponphaiboon et al. (2018) also corroborate the effects of the extraction method on oil stability, affirming that temperature affects the acidity level. The peroxide value was lower in $\mathrm{FO}_{\mathrm{CP}}$ than that of $\mathrm{FO}_{\text {Sox }}(\mathrm{p}=0.001)$ and $\mathrm{FO}_{\mathrm{BD}}(\mathrm{p}=0.028)$. High temperatures and exposure to oxygen (Brum et al., 2009) promote the formation of peroxides, and methods employing solvents are more susceptible to these conditions.

$\mathrm{FO}_{\text {Sox }}$ showed a lower saponification value than $\mathrm{FO}_{\mathrm{CP}}(\mathrm{p}=0.004)$. Since this value is inversely proportional to the average molecular weight of fatty acids (Tavakoli et al., 2018), the difference found in this study indicated that the fatty acids in $\mathrm{FO}_{\text {sox }}$ have higher molecular weight. This was probably because of the solvent's ability to penetrate the food matrix and more easily extract the high-molecular-weight fatty acids.

The higher refractive index $(\mathrm{p}=0.000)$ was found in $\mathrm{FO}_{\mathrm{CP}}$. One factor that affects this index is the degree of unsaturation of the oils; in other words, the greater the number of double bonds, the greater this index (Tavakoli et al., 2018). Taking this observation into consideration, along with the fact that unsaturated fatty acids lose their unsaturation at high temperatures, and the knowledge that the $\mathrm{FO}_{\mathrm{CP}}$ sample had not been exposed to high temperatures, we inferred that this oil contained more unsaturated fatty acids.

The percentage moisture and volatile content of $\mathrm{FO}_{\mathrm{CP}}$ was lower than that of $\mathrm{FO}_{\mathrm{Sox}}(\mathrm{p}=0.000)$ and $\mathrm{FO}_{\mathrm{BD}}(\mathrm{p}=0.000)$. This was probably because evaporation of the solvents used for extraction in the latter samples. Consequently, the oil that showed more reliable values was $\mathrm{FO}_{\mathrm{CP}}$, because it was not influenced by the use of solvents in the method. 
Ribeiro et al.

Table 1. Effect of the extraction method on physicochemical properties of faveleira seed oil (Cnidoscolus quercifolius).

\begin{tabular}{lcrr}
\hline \multicolumn{1}{c}{ Physicochemical properties } & \multicolumn{1}{c}{$\mathrm{FO}_{\text {Sox }}{ }^{1}$} & $\mathrm{FO}_{\mathrm{BD}}{ }^{2}$ & $\mathrm{FO}_{\mathrm{CP}}{ }^{3}$ \\
\hline Acidity $(\%$ oleic acid) & $4.68 \pm 0.02^{\mathrm{a}}$ & $3.79 \pm 0.03^{\mathrm{b}}$ & $1.56 \pm 0.01^{\mathrm{c}}$ \\
Peroxide (mEq/1000 g) & $3.33 \pm 0.83^{\mathrm{a}}$ & $2.00 \pm 0.40^{\mathrm{a}}$ & $0.45 \pm 0.09^{\mathrm{b}}$ \\
Saponification value $(\mathrm{mg} \mathrm{KOH} / \mathrm{g})$ & $215.63 \pm 1.62^{\mathrm{b}}$ & $220.33 \pm 2.02^{\mathrm{ab}}$ & $224.03 \pm 2.03^{\mathrm{a}}$ \\
Refraction index at $40^{\circ} \mathrm{C}$ & $1.4594 \pm 0.0002^{\mathrm{c}}$ & $1.4611 \pm 0.0002^{\mathrm{b}}$ & $1.4645 \pm 0.0006^{\mathrm{a}}$ \\
Moisture and volatile content (\%) & $3.81 \pm 0.34^{\mathrm{a}}$ & $3.07 \pm 0.09^{\mathrm{b}}$ & $0.15 \pm 0.05^{\mathrm{c}}$ \\
Density at $25^{\circ} \mathrm{C}\left(\mathrm{kg} / \mathrm{m}^{3}\right)$ & $903.2 \pm 0.1^{\mathrm{c}}$ & $927.9 \pm 0.2^{\mathrm{a}}$ & $913.8 \pm 0.0^{\mathrm{b}}$ \\
Viscosity at $25^{\circ} \mathrm{C}(\mathrm{Pa} \cdot \mathrm{s})$ & $0.0346 \pm 0.0136^{\mathrm{b}}$ & $0.0282 \pm 0.0100^{\mathrm{c}}$ & $0.0525 \pm 0.0106^{\mathrm{a}}$ \\
\hline
\end{tabular}

${ }^{1} \mathrm{FO}_{\text {Sox }}$ : faveleira seed oil extracted by Soxhlet method; ${ }^{2} \mathrm{FO}_{\mathrm{BD}}$ : faveleira seed oil extracted by Bligh and Dyer method; ${ }^{3} \mathrm{FO}_{\mathrm{CP}}$ : faveleira seed oil extracted by cold-pressing method. Means with different lowercase letters in the same row are statistically different $(\mathrm{p}<0.05)$. The values are shown as means \pm standard deviation in triplicates.

Each of the three oils had different density values; the lowest density was found in $\mathrm{FO}_{\text {Sox }}(\mathrm{p}=0.000)$ and the highest in $\mathrm{FO}_{\mathrm{BD}}(\mathrm{p}=0.000)$. Since the densities of hexane and chloroform are very different $(0.655 \mathrm{~g} / \mathrm{mL}$ and $1.498 \mathrm{~g} / \mathrm{mL}$, respectively) (Al-Hamamre et al., 2012), the densities of $\mathrm{FO}_{\mathrm{Sox}}$ and $\mathrm{FO}_{\mathrm{BD}}$ may have varied because of the presence of traces of hexane and chloroform, respectively. Perdomo et al. (2013) reported different density values for oils extracted using different methods, and they affirmed that some solvents found in the oil might cause density values to vary. These same authors found that the oil extracted by the Soxhlet method and using hexane presented lower density than the oil extracted mechanically by pressing.

The viscosity values of oils extracted using solvent were lower $(\mathrm{p}=0.000)$ than those found in $\mathrm{FO}_{\mathrm{CP}}$ It can be the impact of solvent residues in the oil. Other authors also noted that the cold-pressing method produced oil with higher viscosity than those obtained from solvent extraction (Perdomo et al., 2013).

From the results, it is clear that the extraction methods for obtaining vegetable oils are influenced by factors such as time, temperature, whether solvent is used, and type of solvent used, which in turn influences the physicochemical properties of the oil. The results show that the cold-pressing method is the least influenced by these factors. Thus, cold-pressing is the most useful method when the quality and use of the oil are considered.

\subsection{Tocopherols}

The quantity of alpha- and beta + gamma-tocopherols in faveleira seed oil varied with the extraction method (Figure 2). No alpha- and beta + gamma-tocopherols content was noted in $\mathrm{FO}_{\mathrm{Sox}}$. $\mathrm{FO}_{\mathrm{CP}}$ showed the greatest amount of homologs, which may be attributable to the fact that cold-pressing does not use high temperatures, which degrade tocopherols (Wang et al., 2010). Teh \& Morlock (2015) also reported that tocopherols in cold pressed oils are not significantly affected by the processing conditions.

The alpha-tocopherol content in $\mathrm{FO}_{\mathrm{CP}}$ was lower than that observed in Brazil nut, macadamia nut, hazelnut, and almond oils, but was higher than that observed in pecan oil (Castelo-Branco et al., 2016) and flaxseed oil (Obranović et al., 2015). The beta + gamma-tocopherol content in $\mathrm{FO}_{\mathrm{CP}}$ was lower than that in pumpkin seed oil (Rabrenović et al., 2014).

A significantly lower amount of homologs $(\mathrm{p}<0.05)$ was noted in $\mathrm{FO}_{\mathrm{BD}}$ than in $\mathrm{FO}_{\mathrm{CP}}$. When comparing these two oils,

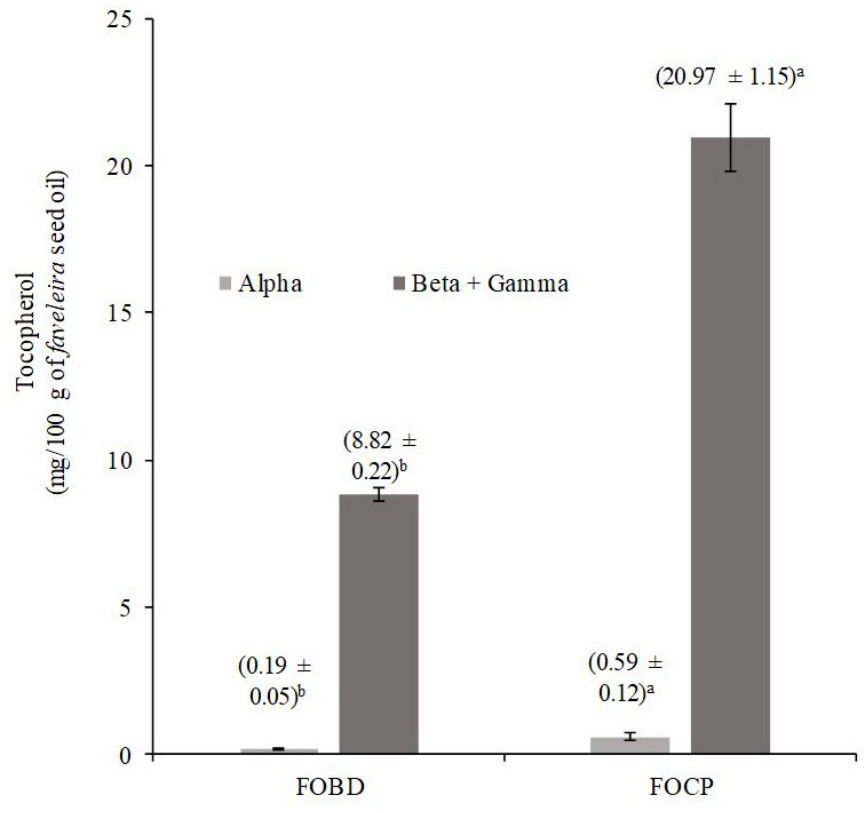

Figure 2. Mean \pm standard error $(n=3)$ of alpha- and beta + gamma-tocopherol concentrations in faveleira seed oil extracted using Bligh-Dyer (FOBD), and cold-press (FOCP) methods. Different lowercase letters above the columns indicate statistically significant differences $(\mathrm{p}<0.05)$ among different extractions methods according to the $t$-test.

the percentage loss of alpha-tocopherols was $68 \%$, while that of beta + gamma-tocopherol was $58 \%$; this occurred because of the high temperatures used in seed drying and evaporation of the solvent. The higher percentage loss of alpha-tocopherol is because of its lower stability than that of beta and gamma-tocopherol, as demonstrated by Wang et al. (2010). The amount of alpha-tocopherols found in $\mathrm{FO}_{\mathrm{CP}}$ and $\mathrm{FO}_{\mathrm{BD}}$ was lower than that beta + gamma-tocopherol (Figure 2). Rabrenović et al. (2014) also observed this trend in pumpkin seed oil.

No alpha- and beta + gamma-tocopherols content was noted in $\mathrm{FO}_{\text {Sox }}$, suggesting that prolonged high temperatures during the oil extraction process, in addition to the high temperatures during seed drying, affected the levels of these tocopherols in the extracted oils. Other authors also showed that high temperatures increase the degradation of tocopherols in oils (Wang et al., 2010).

Soxhlet extraction also resulted in the absence of tocopherols in macadamia oil (Kornsteiner et al., 2006). However, 
Santos et al. (2017) detected tocopherols in faveleira seed oil obtained using Soxhlet extraction. These authors analyze seeds from another state of Brazil. Environmental conditions might have influenced the tocopherol content. Factors such as soil, pluviometric conditions, and environmental temperature influence the composition of plant phytochemicals (Björkman et al., 2011). In addition, Santos et al. (2017) extracted the oil from the faveleira seed by the Soxhlet method for $6 \mathrm{~h}$ and without subjecting the seeds to drying. As tocopherol can be degraded at high temperatures (Wang et al., 2010), the longer Soxhlet extraction and seed drying at $105{ }^{\circ} \mathrm{C}$ might have resulted in higher degradation of these compounds.

The autoxidation of oils during processing and storage is primarily responsible for the deterioration of food quality, from both organoleptic and nutritional points of view (Tuberoso et al., 2007). Considering the loss of alpha- and beta + gamma-tocopherols in faveleira seed oil reported herein, it is essential that an efficient control of oil oxidation and tocopherol degradation be maintained in the food industry (Wang et al., 2010).

\section{Conclusions}

We conclude that cold-pressing extraction resulted in oil with better physicochemical properties for use in human food and leads to the best tocopherols content. Therefore, mechanically extracted oils can be more stable and less susceptible to autoxidation than those extracted using solvents.

\section{Acknowledgements}

This study was financed in part by the Coordenação de Aperfeiçoamento de Pessoal de Nível Superior - Brasil (CAPES) - Finance Code 001 and by Pro-rectory of Research/UFRN (PROPESQ).

\section{References}

Al-Hamamre, Z., Foerster, S., Hartmann, F., Kröger, M., \& Kaltschmitt, M. (2012). Oil extracted from spent coffee grounds as a renewable source for fatty acid methyl ester manufacturing. Fuel, 96, 70-76. http://dx.doi.org/10.1016/j.fuel.2012.01.023.

American Oil Chemists' Society - AOCS. (1995). Official methods and recommended practices of the AOCS. Champaign: AOCS Press.

American Oil Chemists' Society - AOCS. (2009). Official methods and recommended practices of the AOCS (6th ed.). Champaign: AOCS Press.

Anwar, F., Kamal, G. M., Nadeem, F., \& Shabir, G. (2016). Variations of quality characteristics among oils of different soybean varieties. Journal of King Saud University - Science, 28(4), 332-338. https:// doi.org/10.1016/j.jksus.2015.10.001.

Björkman, M., Klingen, I., Birch, A. N. E., Bones, A. M., Bruce, T. J. A., Johansen, T. J., Meadow, R., Molmann, J., Seljasen, R., Smart, L. E., \& Stewart, D. (2011). Phytochemicals of Brassicaceae in plant protection and human health - Influences of climate, environment and agronomic practice. Phytochemistry, 72(7), 538-556. http:// dx.doi.org/10.1016/j.phytochem.2011.01.014. PMid:21315385.

Bligh, E. G., \& Dyer, W. J. (1959). A rapid method of total lipid extraction and purification. Canadian Journal of Biochemistry and Physiology, 37(8), 911-917. http://dx.doi.org/10.1139/o59-099. PMid:13671378.
Brum, A. A. S., Arruda, L. F., \& Regitano-D’Arce, M. A. B. (2009). Métodos de extração e qualidade da fração lipídica de matériasprimas de origem vegetal e animal. Quimica Nova, 32(4), 849-854. http://dx.doi.org/10.1590/S0100-40422009000400005.

Castelo-Branco, V. N., Santana, I., Di-Sarli, V. O., Freitas, S. P., \& Torres, A. G. (2016). Antioxidant capacity is a surrogate measure of the quality and stability of vegetable oils. European Journal of Lipid Science and Technology, 118(2), 224-235. http://dx.doi.org/10.1002/ ejlt.201400299.

Cert, A., Moreda, W., \& Pérez-Camino, M. C. (2000). Chromatographic analysis of minor constituents in vegetable oils. Journal of Chromatography. A, 881(1-2), 131-148. http://dx.doi.org/10.1016/ S0021-9673(00)00389-7. PMid:10905698.

Flakelar, C. L., Luckett, D. J., Howitt, J. A., Doran, G., \& Prenzler, P. D. (2015). Canola (Brassica napus) oil from Australian cultivars shows promising levels of tocopherols and carotenoids, along with good oxidative stability. Journal of Food Composition and Analysis, 42, 179-186. http://dx.doi.org/10.1016/j.jfca.2015.03.010.

Gharby, S., Harhar, H., Bouzoubaa, Z., Asdadi, A., El Yadini, A., \& Charrouf, Z. (2017). Chemical characterization and oxidative stability of seeds and oil of sesame grown in Morocco. Journal of the Saudi Society of Agricultural Sciences, 16(2), 105-111. http://dx.doi. org/10.1016/j.jssas.2015.03.004.

Gharibzahedi, S. M. T., Mousavi, S. M., Hamedi, M., Rezaei, K., \& Khodaiyan, F. (2013). Evaluation of physicochemical properties and antioxidant activities of Persian walnut oil obtained by several extraction methods. Industrial Crops and Products, 45, 133-140. http://dx.doi.org/10.1016/j.indcrop.2012.11.040.

Gliszczynska-Swigło, A., \& Sikorska, E. (2004). Simple reversed-phase liquid chromatography method for determination of tocopherols in edible plant oils. Journal of Chromatography. A, 1048(2), 195-198. http://dx.doi.org/10.1016/j.chroma.2004.07.051. PMid:15481256.

Grilo, E. C., Costa, P. N., Gurgel, C. S. S., Beserra, A. F. L., Almeida, F. N. S., \& Dimenstein, R. (2014). Alpha-tocopherol and gammatocopherol concentration in vegetable oils. Food Science and Technology (Campinas), 34(2), 379-385. http://dx.doi.org/10.1590/ S0101-20612014005000031.

Jing, X., Xiao-Fei, L., \& Yu-Tian, W. (2016). A detection method of vegetable oils in edible blended oil based on three-dimensional fluorescence spectroscopy technique. Food Chemistry, 212, 72-77. http://dx.doi.org/10.1016/j.foodchem.2016.05.158. PMid:27374508.

Kornsteiner, M., Wagner, K., \& Elmadfa, I. (2006). Tocopherols and total phenolics in 10 different nut types. Food Chemistry, 98(2), 381-387. http://dx.doi.org/10.1016/j.foodchem.2005.07.033.

Medeiros, J. M. S., Ribeiro, P. P. C., Freitas, E. P. S., Santos, J. A. B., \& Damasceno, K. S. F. S. C. (2018). Chemical composition of faveleira (Cnidoscolus phyllacanthus) seeds collected in different seasons. Revista Ceres, 65(3), 217-220. http://dx.doi.org/10.1590/0034737x201865030009.

Nierenberg, D. W., \& Nann, S. L. (1992). A method for determining concentrations of retinol, tocopherol, and five carotenoids in human plasma and tissue samples. The American Journal of Clinical Nutrition, 56(2), 417-426. http://dx.doi.org/10.1093/ajcn/56.2.417. PMid:1636620.

Obranović, M., Škevin, D., Kraljić, K., Pospišil, M., Neđeral, S., Blekić, M., \& Putnik, P. (2015). Influence of Climate, Variety and Production Process on Tocopherols, Plastochromanol-8 and Pigments in Flaxseed Oil. Food Technology and Biotechnology, 53(4), 496-504. PMid:27904385.

Perdomo, F. A., Acosta-Osorio, A. A., Herrera, G., Vasco-Leal, J. F., Mosquera-Artamonov, J. D., Millan-Malo, B., \& Rodriguez-Garcia, 
M. E. (2013). Physicochemical characterization of seven Mexican Ricinus communis L. seeds \& oil contentes. Biomass and Bioenergy, 48, 17-24. http://dx.doi.org/10.1016/j.biombioe.2012.10.020.

Podda, M., Weber, C., Traber, M. G., \& Packer, L. (1996). Simultaneous determination of tissue tocopherols, tocotrienols, ubiquinols, and ubiquinones. Journal of Lipid Research, 37(4), 893-901. PMid:8732789.

Ponphaiboon, J., Limmatvapirat, S., Chaidedgumjorn, A., \& Limmatvapirat, C. (2018). Physicochemical property, fatty acid composition, and antioxidant activity of ostrich oils using different rendering methods. Lebensmittel-Wissenschaft + Technologie, 93, 45-50. http://dx.doi. org/10.1016/j.lwt.2018.03.024.

Rabrenović, B. B., Dimić, E. B., Novaković, M. M., Tesević, V. V., \& Basić, Z. N. (2014). The most important bioactive components of cold pressed oil from different pumpkin (Cucurbita pepo L.) seeds. Food Science and Technology (Campinas), 55, 521-527.

Ribeiro, P. P. C., Silva, D. M. L., Assis, C. F., Correia, R. T. P., \& Damasceno, K. S. F. S. C. (2017). Bioactive properties of faveleira (Cnidoscolus quercifolius) seeds, oil and press cake obtained during oilseed processing. PLoS One, 12(8), 1-12. http://dx.doi.org/10.1371/ journal.pone.0183935. PMid:28846740.

Santos, K. A., Aragão, O. P. Fo., Aguiar, C. M., Milinsk, M. C., Sampaio, S. C., Palú, F., \& Silva, E. A. (2017). Chemical composition, antioxidant activity and thermal analysis of oilextracted from favela (Cnidoscolus quercifolius) seeds. Industrial Crops and Products, 97, 368-373. http:// dx.doi.org/10.1016/j.indcrop.2016.12.045.

Silva, S. I., Oliveira, A. F. M., Negri, G., \& Salatino, A. (2014). Seed oils of Euphorbiaceae from the Caatinga, a Brazilian tropical dry forest. Biomass and Bioenergy, 69, 124-134. http://dx.doi.org/10.1016/j. biombioe.2014.07.010.
Tavakoli, J., Emadi, T., Hashemi, S. M. B., Mousavi Khaneghah, A., Munekata, P. E. S., Lorenzo, J. M., Brnčić, M., \& Barba, F. J. (2018). Chemical properties and oxidative stability of Arjan (Amygdalus reuteri) kernel oil as emerging edible oil. Food Research International, 107, 378-384. http://dx.doi.org/10.1016/j.foodres.2018.02.002. PMid:29580498.

Teh, S., \& Morlock, G. E. (2015). Effect-directed analysis of cold-pressed hemp, flax and canola seed oils by planar chromatography linked with (bio)assays and mass spectrometry. Food Chemistry, 187, 460-468. http://dx.doi.org/10.1016/j.foodchem.2015.04.043. PMid:25977051.

Teixeira, G. L., Ávila, S., Silveira, J. L. M., Ribani, M., \& Ribani, R. H. (2018). Chemical, thermal and rheological properties and stability of sapucaia (Lecythis pisonis) nut oils A potential source of vegetable oil in industry. Journal of Thermal Analysis and Calorimetry, 131(3), 2105-2121. http://dx.doi.org/10.1007/s10973-017-6742-1.

Traber, M. G. (2012). Vitamin E. In J. W. Erdman Jr, I. A. Macdonald, \& S. H. Zeisel (Eds.), Present knowledge in nutrition (cap. 14, pp. 214-229). Ames: A John Wiley \& Sons Ltd.

Tuberoso, C. I. G., Kowalczyk, A., Sarritzu, E., \& Cabras, P. (2007). Determination of antioxidant compounds and antioxidant activity in commercial oilseeds for food use. Food Chemistry, 103(4), 14941501. http://dx.doi.org/10.1016/j.foodchem.2006.08.014.

Wang, S., Hwang, H., Yoon, S., \& Choe, E. (2010). Temperature dependence of autoxidation of perilla oil and tocopherol degradation. Journal of Food Science, 75(6), 498-505. http://dx.doi.org/10.1111/j.17503841.2010.01681.x. PMid:20722903.

Xu, H., Zhu, L., Dong, J., Wei, Q., \& Lei, M. (2015). Composition of Catalpa ovata seed oil and flavonoids in seed meal as well as their antioxidant activities. Journal of the American Oil Chemists' Society, 92(3), 361-369. http://dx.doi.org/10.1007/s11746-015-2595-6. 